\title{
Early impact of oil palm planting density on vegetative and oil yield variables in West Africa
}

\author{
Xavier Bonneau ${ }^{1, \star}$, Pieter Vandessel ${ }^{2}$, Maxwell Buabeng ${ }^{2}$ and Charles Erhahuyi ${ }^{2}$ \\ 1 CIRAD, TA B-34 / 02, Avenue Agropolis, 34398 Montpellier Cedex 5, France \\ 2 SIAT, Presco-plc, km 22 Benin-Sapele road, P.O.B. 7061, Benin City, Edo State, Nigeria
}

Received 14 November 2013 - Accepted 18 February 2014

\begin{abstract}
A range of various different planting distances (from 7.5 to $9.5 \mathrm{~m}$ ) between oil palms were tested using an equilateral triangle design in a plantation density experiment which was settled in an oil palm commercial plantation in Nigeria. Climatic conditions were quite stable, with two seasons and around $2000 \mathrm{~mm}$ of annual rainfall. The soil was of desaturated ferralitic type, sandy on the surface, deep and without coarse elements. The early impact of plantation density was analysed at eight years after planting. Some early signs of depressive effect on yields were found for high planting densities (180 and $205 \mathrm{p} / \mathrm{ha}$ ). Such a negative impact was not severe enough to counteract the effects of a higher number of palms per hectare. As a consequence, a gradient could be observed as yields (in tons of bunches per hectare) increased with density. We can anticipate that the competition effect between palms will increase over time with high densities, so that the counteracting point ought to be reached in a few years. A thinning treatment has been included in the protocol. Thinning was carried out at the end of the eight-year period.
\end{abstract}

Keywords: Oil palm / planting density / spacing / thinning / yield

Résumé - Premiers effets de la densité de plantation sur les variables végétatives et de production du palmier à huile en Afrique de l'Ouest. Une gamme de différentes distances de plantation entre palmiers à huile (7,5 à 9,5 m) a été testée dans un dispositif en triangle équilatéral. L'expérience de densité de plantation a été établie dans une plantation de palmier à huile au Nigéria. Le climat est très régulier, à deux saisons avec environ $2000 \mathrm{~mm}$ de précipitations annuelles. Le sol est de type ferralitique désaturé, sableux en surface, profond, sans éléments grossiers. Un premier bilan a été établi à huit ans après plantation. Des signes d'effet dépressif des fortes densités de plantation (180 et 205 p/ha) sur le rendement ont été mis en évidence. Cet effet dépressif n'est toutefois pas assez fort pour contrebalancer l'augmentation du nombre d'arbres à l'hectare, de sorte qu'il existe un gradient de rendement (tonnes de régimes à l'hectare) croissant avec la densité. Un éclaircissage des palmiers à huit ans est inclus dans le protocole.L'effet concurrentiel entre palmiers va augmenter avec le temps dans les fortes densités, de sorte que le point de compensation devrait être atteint dans quelques années.

Mots clés : Palmier à huile / densité de plantation / écartement / éclaircissage / rendement

\section{Introduction}

The spacing between oil palms is considered as a major contributor to oil yields under planting designs following an equilateral triangle model as used in various monocultures (Prévot et al., 1955; Smith, 1972). We are investigating the optimum spacing which might be able to ensure the highest cumulative production over a cropping cycle of around 25 years. The plantation density must fit between too large a spacing that makes inadequate use of incident radiation and too small a spacing that leads to excessive competition between palms with an anticipated depressive effect on oil yields.

\footnotetext{
^ Correspondence: xavier.bonneau@cirad.fr
}

There are several recent studies describing the impact of planting density in oil palm plantations (Henson et al., 2003; Breure, 2010; Palat et al., 2012; Rafii et al., 2013). Even if planting material has changed since the 1990s and such has the climate in many places, some preconceived ideas have unfortunately still not changed... It was therefore found useful to set up a planting density trial, using a widely used type of planting material on a very widespread soil type in West Africa.

Results were analysed with reference not only to the oil palm, but also to the coconut palm, as these two members of the Arecaceae family share the same type of foliage architecture thus some of the results obtained for one palm can be extrapolated to the other following appropriate adjustments. 


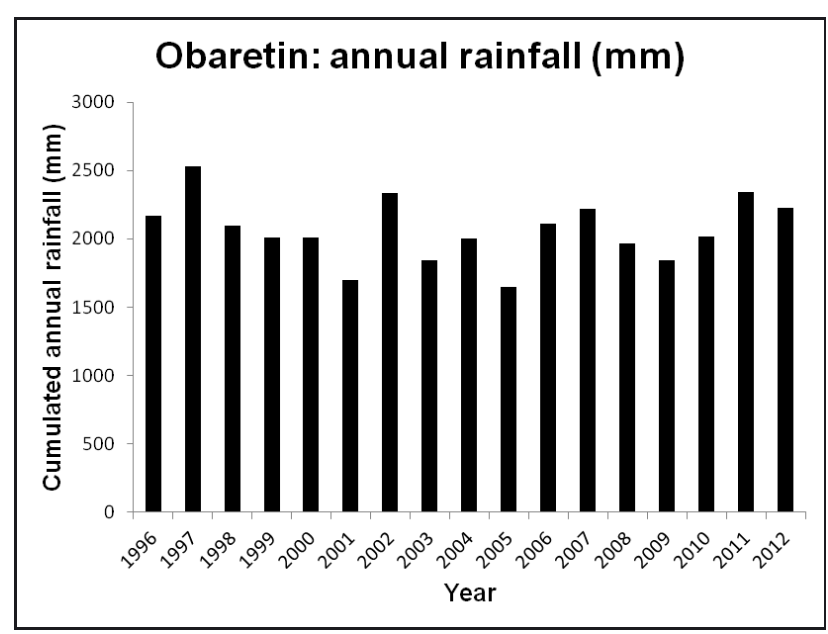

Fig. 1. Cumulative rainfall per year on the experimental plot (mm).

\section{Materials and methods}

\subsection{Experimental conditions}

The Presco Plc plantation is located at Obaretin near Benin City, Edo State in Nigeria. It occupies an area of around 6000 hectares. Two other plantations belonging to the same company are located in the same region.

The terrain in the region is flat, over a vast sedimentary formation called the Continental Terminal. The very uniform soils are of a ferralitic type; they are deep, very sandy on the surface, with a gradual increase in clay content with depth, without any coarse elements. The soils are of low chemical fertility which can be compensated for by an appropriate organic/inorganic fertilization scheme in order to create sub-optimum conditions. These are a prerequisite for the expression of the planting density effect as underlined by several authors (Smith, 1972; Ochs, 1988; de Taffin et al., 1992; Henson et al., 2003).

Climatic data show two seasons: a dry season from November to April (the driest months being December and January) and a wet season which occurs from May to October providing an average annual rainfall of $2062 \mathrm{~mm}$ (Fig. 1). Rainfall is well distributed and a moderate water deficit occurs. Under these conditions and unless an exceptionally dry period occurs (which did not happen to date) it is not very likely to monitor a response of the oil palm to water stress which depends on the planting density (Coomans, 1974, Bonneau 1991; Palat et al., 2012). The planting density experiment was carried out in a second generation plantation established in July 2005 , on a previous oil palm cover which occupied the plot for 25 years. The stems of the felled old palms were pushed to the edge of the experimental plot.

\subsection{Planting material}

The planting material used since 2002 by the Presco Company is of Pobè C1001F type which belongs to the Deli $\times$ La Mé group and was derived from crosses between Dura DA115 D and Pisifera LM2T selected parents. This material has proven tolerant to vascular wilt.
Table 1. Planting densities and experimental design.

\begin{tabular}{cccc}
\hline Treatment & $\begin{array}{c}\text { Initial planting } \\
\text { density } \\
\text { (number of palms } \\
\text { per hectare) }\end{array}$ & $\begin{array}{c}\text { Distance between } \\
\text { palms } \\
\text { (in metres) }\end{array}$ & $\begin{array}{c}\text { Management of } \\
\text { planting density }\end{array}$ \\
\hline D 1 & 128 & 9.5 & fixed \\
D 2 & 143 & 9 & fixed \\
D 3 & 160 & 8.5 & fixed \\
D 4 & 180 & 8 & fixed \\
D 5 & 180 & 8 & thinned (1) \\
D 6 & 205 & 7.5 & fixed \\
\hline
\end{tabular}

(1) By eliminating every 7 th palm at year 8 (one central palm per hexagon) in order to reduce the planting density from 180 to $154 \mathrm{p} / \mathrm{ha}$.

\subsection{Statistical design}

Our statistical design followed a randomized complete block with 4 replicates of 6 treatments as described in Table 1. We have included a treatment with a later reduction in density, as the question frequently raised by growers is whether it is more efficient to plant at high density in order to benefit from high yields on young palms when the competition effect between palms is still weak, then to thin the plant cover in order to avoid a drop in yields in the second part of the cycle when competition effect between palms negatively impacts productivity.

Each of the 24 unit plots was made of 72 palms, planted in 9 rows of 8 palms with a double border, i.e. 20 useful central palms (5 rows of 4 ). Where necessary, any gaps between the unit plots have been filled with neutral palms. The total area of the trial is 12.7 hectares.

Palms involved in the experiment have been planted following an equilateral triangle design, which is more efficient for the interception of solar radiation given the foliage architecture of the plant (Prévot et al., 1955; Smith, 1972).

\subsection{Fertilization regime}

Palms under study were given a uniform fertilization regime per palm for the first four years then uniform fertilization per unit area from the fifth year onwards (Tab. 2). The aim was to adjust the fertilizer's input so that mineral nutrition never acted as a limiting factor. Annual leaf analyses were used in order to continuously monitor the mineral nutrition status of palms and to adjust the fertilization regime accordingly. Table 3 describes changes in nutrition data for the whole experiment through the analysis of leaf mineral contents for the main nutrients.

\subsection{Trial management}

The trial suffered some setbacks in the early stages. Early attacks from wild rodents (Tryonomys swinderianus) destroyed young plants and $4 \%$ of the palms had to be replaced in April 2006 then another 5\% in May 2007. In addition, a bush fire devastated the plot in February 2008, although it killed 
Table 2. Fertilization regimes applied after planting.

\begin{tabular}{ccccc}
\hline A: Fertilization regime per palm for young palms (g of fertilizer per palm) \\
\hline \multirow{2}{*}{ Age of the palms (MAP) } & \multicolumn{4}{c}{ Type of fertilizer } \\
\cline { 2 - 5 } & compound & KCl & kieserite & borax \\
\hline 1 & 500 & $\mathrm{x}$ & $\mathrm{x}$ & $\mathrm{x}$ \\
3 & 500 & $\mathrm{x}$ & $\mathrm{x}$ & $\mathrm{x}$ \\
9 & 500 & $\mathrm{x}$ & $\mathrm{x}$ & $\mathrm{x}$ \\
15 & 500 & $\mathrm{x}$ & $\mathrm{x}$ & $\mathrm{x}$ \\
22 & 1000 & $\mathrm{x}$ & $\mathrm{x}$ & $\mathrm{x}$ \\
24 & 1000 & $\mathrm{x}$ & $\mathrm{x}$ & $\mathrm{x}$ \\
27 & 1000 & $\mathrm{x}$ & $\mathrm{x}$ & $\mathrm{x}$ \\
33 & 2000 & $\mathrm{x}$ & $\mathrm{x}$ & $\mathrm{x}$ \\
40 & $\mathrm{x}$ & $\mathrm{x}$ & 500 & $\mathrm{x}$ \\
47 & $\mathrm{x}$ & 2000 & $\mathrm{x}$ & $\mathrm{x}$ \\
48 & $\mathrm{x}$ & $\mathrm{x}$ & 500 & $\mathrm{x}$ \\
60 & $\mathrm{x}$ & $\mathrm{x}$ & $\mathrm{x}$ & 50 \\
\hline
\end{tabular}

\begin{tabular}{|c|c|c|c|c|}
\hline \multicolumn{5}{|c|}{$\begin{array}{l}\text { B: fertilization regime per hectare on mature palms - after year } 4- \\
\qquad(\mathrm{kg} \text { of fertilizer per hectare) }\end{array}$} \\
\hline \multirow{2}{*}{ Age of the palms (MAP) } & \multicolumn{4}{|c|}{ Type of fertilizer } \\
\hline & $\overline{\mathrm{KCl}}$ & EFB & TSP & kieserite \\
\hline 59 & 286 & $\mathrm{x}$ & $\mathrm{x}$ & $\mathrm{x}$ \\
\hline 72 & 357.5 & $\mathrm{x}$ & $\mathrm{x}$ & $\mathrm{x}$ \\
\hline 83 & $\mathrm{x}$ & 12200 & $\mathrm{x}$ & $\mathrm{x}$ \\
\hline 83 & 286 & $\mathrm{x}$ & $\mathrm{x}$ & $\mathrm{x}$ \\
\hline 95 & $\mathrm{x}$ & 35000 & $\mathrm{x}$ & $\mathrm{x}$ \\
\hline 95 & 286 & $\mathrm{x}$ & $\mathrm{x}$ & $\mathrm{x}$ \\
\hline
\end{tabular}

NB 1: MAP = Months after planting. NB 2: 12-12-17-2 = mixed compound expressed in $\% \mathrm{~N}_{-} \mathrm{P}_{2} \mathrm{O}_{5}-\mathrm{K}_{2} \mathrm{O}-\mathrm{MgO}$ content. NB3: EFB = Empty Fruit Bunch.

only 3 palms. This result confirms the strong resistance of young oil palms to fire and in our case such resistance was improved by the very good upkeep of the plot with clean circles around palms of wide $(2 \mathrm{~m})$ radius.

The replacement palms grew satisfactorily. At 8 years after planting (July 2013) the difference in stem height and foliage bulk between palms replaced in 2006 and original palms was virtually no longer visible, while the palms replaced in 2007 were well on the way to catching up.

In addition, a few palms have been killed by lightning over the years and they were replaced by transplanting a palm of the equivalent age taken from a neighbouring block, in order to maintain the canopy as uniform as possible.

Lastly, frequent attacks by Oryctes spp have caused some frond breakage and sometimes resulted in deformed young leaves. The affected palms were removed from the list of observed palms until they recovered normal leaf architecture.

\subsection{Measured variables}

Two types of variables were monitored during the experiment, namely vegetative and yield variables. Girth of palms was measured at ground level each year. Frond length was measured yearly from the base of the petiole to the tip of the rachis. Starting at year 6 and then during each following year, we measured stem height from the ground to the petiole base of frond 33. Starting at year 7 and then during each following year, the projection on the ground of frond 33 was evaluated from the base of the stem to the tip of the frond. As the frond grows in a quite horizontal position, its tip is considered as giving the span of the oil palm foliage which can be considered as a sphere.

Several oil yield variables were also recorded. Indeed, during each harvesting visit (every 10 days), the number of ripe bunches per palm and the average bunch weight were recorded. Three variables were then analysed on a yearly basis, namely: bunch number per palm, average bunch weight and total bunch weight per palm, from which the total bunch weight per hectare is calculated for each of the treatments.

\section{Results}

Table 3 shows that mineral nutrition of palms under study was satisfactory as none of the analysed nutrients reached a deficiency threshold during the observation period. Mineral nutrition was found to be uniform, as no significant difference could be found between treatments for almost all analysed nutrients, except nitrogen during years 7 and 8. Nevertheless, even if they were significant, the recorded differences in leaf $N$ content were of low amplitude and they were found to occur within a variation range well over the $N$ critical level. It was therefore concluded that the nutritional status of the palms did not interfere with the effect of planting density.

Tables 4-7 present changes in vegetative growth variables. No density treatment effect could be found for both girth and stem height. The girth of palms was still increasing at year 8, although it was in the process of late stabilization. Stem height 
X. Bonneau et al.: OCL 2014, 21(4) A401

Table 3. Analysis of leaf contents in nitrogen, phosphorus, potassium, magnesium and chlorine (percentage of dry matter).

\begin{tabular}{|c|c|c|c|c|c|c|c|c|}
\hline \multirow{2}{*}{ Treatment } & \multicolumn{4}{|c|}{ Leaf nitrogen } & \multicolumn{4}{|c|}{ Leaf phosphorus } \\
\hline & 2009 & 2010 & 2011 & 2012 & 2009 & 2010 & 2011 & 2012 \\
\hline D 1 & 3.12 & 3.04 & $2.96 \mathrm{abc}$ & $3.01 \mathrm{ab}$ & 0.171 & 0.173 & 0.173 & 0.186 \\
\hline D 2 & 3.09 & 3.03 & $2.99 \mathrm{ab}$ & $3.07 \mathrm{a}$ & 0.169 & 0.170 & 0.172 & 0.185 \\
\hline D 3 & 3.12 & 3.06 & $3.02 \mathrm{a}$ & $3.02 \mathrm{ab}$ & 0.171 & 0.174 & 0.175 & 0.185 \\
\hline D 4 & 3.13 & 3.07 & $2.92 \mathrm{bc}$ & $3.00 \mathrm{abc}$ & 0.170 & 0.173 & 0.170 & 0.183 \\
\hline D 5 & 3.05 & 3.05 & $2.90 \mathrm{bc}$ & $2.92 \mathrm{c}$ & 0.168 & 0.172 & 0.171 & 0.182 \\
\hline D 6 & 3.06 & 3.04 & $2.88 \mathrm{c}$ & $2.95 \mathrm{bc}$ & 0.168 & 0.174 & 0.171 & 0.184 \\
\hline Mean & 3.10 & 3.05 & 2.95 & 2.95 & 0.170 & 0.173 & 0.172 & 0.184 \\
\hline Threshold & $\mathrm{ns}$ & ns & $<0.05$ & $<0.01$ & $\mathrm{~ns}$ & ns & $\mathrm{ns}$ & ns \\
\hline LSD & & & 0.09 & 0.07 & & & & \\
\hline \multirow{2}{*}{ Treatment } & \multicolumn{4}{|c|}{ Leaf potassium } & \multicolumn{4}{|c|}{ Leaf magnesium } \\
\hline & 2009 & 2010 & 2011 & 2012 & 2009 & 2010 & 2011 & 2012 \\
\hline D 1 & 0.879 & 0.831 & 0.875 & 0.921 & 0.313 & 0.285 & 0.285 & 0.251 \\
\hline D 2 & 0.876 & 0.900 & 0.874 & 0.932 & 0.307 & 0.283 & 0.264 & 0.211 \\
\hline D 3 & 0.854 & 0.877 & 0.842 & 0.895 & 0.295 & 0.284 & 0.273 & 0.231 \\
\hline D 4 & 0.867 & 0.862 & 0.837 & 0.866 & 0.316 & 0.290 & 0.297 & 0.252 \\
\hline D 5 & 0.830 & 0.837 & 0.844 & 0.890 & 0.323 & 0.309 & 0.290 & 0.253 \\
\hline D 6 & 0.816 & 0.860 & 0.816 & 0.847 & 0.311 & 0.294 & 0.292 & 0.249 \\
\hline Mean & 0.854 & 0.861 & 0.848 & 0.892 & 0.311 & 0.291 & 0.284 & 0.241 \\
\hline Threshold & ns & ns & ns & ns & ns & ns & ns & ns \\
\hline \multirow{2}{*}{ Treatment } & \multicolumn{4}{|c|}{ Leaf chlorine } & & & & \\
\hline & 2009 & 2010 & 2011 & 2012 & & & & \\
\hline D 1 & 0.532 & 0.522 & 0.490 & 0.525 & & & & \\
\hline D 2 & 0.583 & 0.565 & 0.533 & 0.525 & & & & \\
\hline D 3 & 0.553 & 0.565 & 0.524 & 0.510 & & & & \\
\hline D 4 & 0.552 & 0.535 & 0.566 & 0.510 & & & & \\
\hline D 5 & 0.552 & 0.539 & 0.507 & 0.506 & & & & \\
\hline D 6 & 0.563 & 0.542 & 0.553 & 0.517 & & & & \\
\hline Mean & 0.556 & 0.545 & 0.529 & 0.516 & & & & \\
\hline Threshold & ns & ns & ns & ns & & & & \\
\hline
\end{tabular}

NB 1: Threshold $=$ threshold of statistical significance, as; not significant (ns) or significant under 5\% probability of error $(<0.05)$ or highly significant under $1 \%$ probability of error $(<0.01 \%)$. NB 2 : LSD $=$ lowest significant difference under the $5 \%$ threshold. NB $3:$ a,b,c $\ldots=$ classification of treatments according to the Duncan test at $5 \%$.

Table 4. Changes in girth $(\mathrm{m})$ with the age of oil palms planted at various densities.

\begin{tabular}{ccccccccc}
\hline \multirow{2}{*}{ Treatment } & \multicolumn{7}{c}{ Age of palms in MAP } \\
\cline { 2 - 9 } & 12 & 24 & 36 & 48 & 60 & 72 & 84 & 96 \\
\hline D 1 & 0.61 & 1.00 & 1.64 & 2.06 & 2.38 & 2.49 & 2.62 & 2.69 \\
D 2 & 0.57 & 0.96 & 1.59 & 2.00 & 2.36 & 2.49 & 2.61 & 2.70 \\
D 3 & 0.56 & 0.97 & 1.57 & 2.00 & 2.36 & 2.43 & 2.56 & 2.66 \\
D 4 & 0.58 & 1.00 & 1.71 & 2.10 & 2.42 & 2.50 & 2.59 & 2.65 \\
D 5 & 0.56 & 1.00 & 1.62 & 2.02 & 2.36 & 2.50 & 2.60 & 2.68 \\
D 6 & 0.62 & 1.03 & 1.71 & 2.09 & 2.40 & 2.53 & 2.60 & 2.65 \\
\hline Mean & 0.58 & 0.99 & 1.64 & 2.05 & 2.38 & 2.49 & 2.60 & 2.67 \\
Threshold & ns & ns & ns & ns & ns & ns & ns & ns \\
\hline
\end{tabular}

increased regularly at the rate of $\mathrm{ca} 30 \mathrm{~cm}$ per year. No sign of stem bolting could be observed when high densities were used, which is not surprising at this age: bolting uses to occur after year 10 under similar planting densities (Palat et al., 2012). The frond length was still increasing at year 8 after planting and a gradient could be evidenced: the closer together the palms were planted, the longer the frond.

Tables 8-11 and Figure 2 provide yearly production data compiled from 6 harvesting campaigns (year 3 to 8).

A significant depressive effect of planting density was found in years 6 and 8 on the bunch number per palm variable at the highest densities. Conversely, no effect could be found on the average bunch weight variable. The fact that spacing between palms had a greater effect on the number of fruits than on their individual weight has been shown in both the oil palm (Henson et al., 2003) and the coconut palm (Coomans, 1974; Fernando et al., 1996).

Figure 2 shows that the difference between the treatments compared to treatment D1, considered as the control, has a tendency to decrease with the age of palms. This is true for the highest densities (D4, D5 and D6), although some stabilization 
X. Bonneau et al.: OCL 2014, 21(4) A401

Table 5. Changes in frond length $(\mathrm{m})$ with the age of oil palms planted at various densities.

\begin{tabular}{ccccccccc}
\hline \multirow{2}{*}{ Treatment } & \multicolumn{7}{c}{ Age of palms in MAP } \\
\cline { 2 - 9 } & 12 & 24 & 36 & 48 & 60 & 72 & 84 & 96 \\
\hline D 1 & 1.59 & 2.34 & 3.00 & 3.87 & 4.68 & $5.20 \mathrm{bc}$ & 5.27 & $5.69 \mathrm{c}$ \\
D 2 & 1.51 & 2.19 & 2.89 & 3.77 & 4.61 & $5.12 \mathrm{c}$ & 5.48 & $5.73 \mathrm{c}$ \\
D 3 & 1.52 & 2.26 & 3.06 & 3.85 & 4.76 & $5.25 \mathrm{abc}$ & 5.58 & $5.89 \mathrm{bc}$ \\
D 4 & 1.56 & 2.30 & 3.22 & 4.04 & 4.85 & $5.50 \mathrm{ab}$ & 5.52 & $6.04 \mathrm{ab}$ \\
D 5 & 1.50 & 2.25 & 3.11 & 3.87 & 4.79 & $5.37 \mathrm{abc}$ & 5.70 & $6.04 \mathrm{ab}$ \\
D 6 & 1.56 & 2.29 & 3.20 & 4.05 & 4.97 & $5.52 \mathrm{a}$ & 5.60 & $6.13 \mathrm{a}$ \\
\hline Mean & 1.54 & 2.27 & 3.08 & 3.91 & 4.78 & 5.33 & 5.53 & 5.92 \\
Threshold & ns & ns & ns & ns & ns & $<0.05$ & ns & $<0.01$ \\
LSD & & & & & & 0.28 & & 0.20 \\
\hline
\end{tabular}

NB: up to MAP 72 inclusive, the length of frond 17 was measured. From MAP 84 inclusive onwards, low frond was measured.

Table 6. Changes in stem height $(\mathrm{m})$ with the age of oil palms planted at various densities.

\begin{tabular}{cccc}
\hline \multirow{2}{*}{ Treatment } & \multicolumn{3}{c}{ Age of palms in MAP } \\
\cline { 2 - 4 } & 72 & 84 & 96 \\
\hline D 1 & 0.81 & 1.08 & 1.38 \\
D 2 & 0.84 & 1.11 & 1.40 \\
D 3 & 0.83 & 1.09 & 1.42 \\
D 4 & 0.87 & 1.14 & 1.48 \\
D 5 & 0.83 & 1.02 & 1.38 \\
D 6 & 0.88 & 1.15 & 1.45 \\
\hline Mean & 0.84 & 1.10 & 1.42 \\
Threshold & ns & ns & ns \\
\hline
\end{tabular}

Table 7. Changes in the distance from the stem to the ground projection of the tip of frond $33(\mathrm{~m})$ with the age of oil palms planted at various densities.

\begin{tabular}{ccc}
\hline \multirow{2}{*}{ Treatment } & \multicolumn{2}{c}{ Age of palms in MAP } \\
\cline { 2 - 3 } & 84 & 96 \\
\hline D 1 & 4.69 & $4.86 \mathrm{~b}$ \\
D 2 & 4.70 & $4.94 \mathrm{~b}$ \\
D 3 & 4.77 & $5.05 \mathrm{ab}$ \\
D 4 & 4.92 & $5.16 \mathrm{a}$ \\
D 5 & 4.85 & $5.19 \mathrm{a}$ \\
D 6 & 4.93 & $5.22 \mathrm{a}$ \\
\hline Mean & 4.81 & 5.07 \\
Threshold & ns & $<0.01$ \\
LSD & & 0.20 \\
\hline
\end{tabular}

has been recorded for the lowest densities: at $+20 \%$ level for D3 compared to D1 and at $+10 \%$ for D2 compared to D1.

We will carefully monitor this ongoing density trial in the coming years in order to assess some of our early findings: stabilization of yields between 128 and 160 p/ha and decrease at 180 and $205 \mathrm{p} / \mathrm{ha}$.

\section{Discussion}

Planting oil palm at high densities ( $>160 \mathrm{p} / \mathrm{ha}$ ) was found to be still beneficial in terms of yield up to at least eight years after planting. The increase in the number of palms per hectare was found to compensate for the induced drop in bunch weight
Table 8. Changes in the annual FFB yield per palm $(\mathrm{kg})$ in oil palms planted at various densities.

\begin{tabular}{ccccccc}
\hline \multirow{2}{*}{ Treatment } & \multicolumn{7}{c}{ Year of planting } \\
\cline { 2 - 7 } & 3 & 4 & 5 & 6 & 7 & 8 \\
\hline D 1 & $2.5 \mathrm{ab}$ & 27.2 & 34.7 & 81.0 & 70.0 & $110.2 \mathrm{ab}$ \\
D 2 & $1.5 \mathrm{c}$ & 27.5 & 35.8 & 79.4 & 61.2 & $114.4 \mathrm{a}$ \\
D 3 & $1.7 \mathrm{bc}$ & 29.9 & 36.6 & 75.3 & 64.6 & $109.9 \mathrm{ab}$ \\
D 4 & $3.0 \mathrm{a}$ & 34.4 & 33.6 & 74.2 & 56.9 & $98.9 \mathrm{bc}$ \\
D 5 & $1.5 \mathrm{c}$ & 29.9 & 35.0 & 66.6 & 59.8 & $93.2 \mathrm{c}$ \\
D 6 & $2.7 \mathrm{a}$ & 36.1 & 29.1 & 66.6 & 59.2 & $91.2 \mathrm{c}$ \\
\hline Mean & 2.2 & 30.8 & 34.1 & 73.9 & 62.0 & 103.0 \\
Threshold & $<0.01$ & ns & ns & ns & ns & $<0.05$ \\
LSD & 0.9 & & & & & 14.1 \\
\hline
\end{tabular}

Table 9. Changes in the cumulative FFB yield per palm $(\mathrm{kg})$ in oil palms planted at various densities.

\begin{tabular}{cccc}
\hline \multirow{2}{*}{ Treatment } & \multicolumn{3}{c}{ Year of planting } \\
\cline { 2 - 4 } & 6 & 7 & 8 \\
\hline D 1 & 145.5 & 215.4 & 325.8 \\
D 2 & 144.2 & 205.4 & 319.7 \\
D 3 & 143.5 & 208.1 & 318.1 \\
D 4 & 145.2 & 202.1 & 301.0 \\
D 5 & 133.0 & 192.8 & 286.0 \\
D 6 & 134.4 & 193.7 & 284.8 \\
\hline Mean & 141.0 & 202.9 & 305.9 \\
Threshold & ns & ns & ns \\
\hline
\end{tabular}

per palm. When cumulated bunch weight per hectare was estimated over eight years, the highest planting density (205 p/ha) was found to generate a $40 \%$ higher bunch weight per hectare than the lowest density (128 p/ha).

The relationship between the planting density effect and the age of plants has been demonstrated in both the oil palm (Prévot et al.; 1955; Chen, 1989; Rafii et al., 2013) and the coconut palm (Foale, 1968; Coomans, 1974; Tan Yap Pau et al., 1984). In the oil palm, within the variation ranges tested, the maximum planting density effect occurs after year 8 and more often between year 10 and year 12 (Chen et al., 1989; Palat et al., 2012; Rafii et al., 2013). In our experiment, it is therefore not surprising to record a benefit in terms of yield at high densities at year 8 and it is highly probable that the 
X. Bonneau et al.: OCL 2014, 21(4) A401

Table 10. Annual changes in yield (tons FFB/ha) in oil palms planted at various densities.

\begin{tabular}{ccccccc}
\hline \multirow{2}{*}{ Treatment } & \multicolumn{7}{c}{ Year of planting } \\
\cline { 2 - 7 } & 3 & 4 & 5 & 6 & 7 & 8 \\
\hline D 1 & $0.32 \mathrm{~b}$ & $3.48 \mathrm{~d}$ & 4.44 & 10.37 & 8.98 & $14.11 \mathrm{~b}$ \\
D 2 & $0.21 \mathrm{~b}$ & $3.93 \mathrm{~cd}$ & 5.12 & 11.35 & 8.75 & $16.36 \mathrm{ab}$ \\
D 3 & $0.27 \mathrm{~b}$ & $4.78 \mathrm{bcd}$ & 5.86 & 12.05 & 10.34 & $17.59 \mathrm{a}$ \\
D 4 & $0.54 \mathrm{a}$ & $6.19 \mathrm{ab}$ & 6.04 & 13.35 & 10.23 & $17.80 \mathrm{a}$ \\
D 5 & $0.27 \mathrm{~b}$ & $5.38 \mathrm{bc}$ & 6.30 & 12.00 & 10.76 & $16.78 \mathrm{a}$ \\
D 6 & $0.55 \mathrm{a}$ & $7.40 \mathrm{a}$ & 5.96 & 13.65 & 12.02 & $18.69 \mathrm{a}$ \\
\hline Mean & 0.36 & 5.19 & 5.62 & 12.13 & 10.18 & 16.89 \\
Threshold & $<0.01$ & $<0.01$ & ns & ns & ns & $<0.05$ \\
LSD & 0.16 & 1.59 & & & & 2.33 \\
\hline
\end{tabular}

Table 11. Changes in cumulative yield (in tons FFB/ha) in oil palms planted at various densities.

\begin{tabular}{cccc}
\hline \multirow{2}{*}{ Treatment } & \multicolumn{3}{c}{ Year of planting } \\
\cline { 2 - 4 } & 6 & 7 & 8 \\
\hline D 1 & $18.6 \mathrm{e}$ & $27.6 \mathrm{~d}$ & $41.7 \mathrm{~d}$ \\
D 2 & $20.6 \mathrm{de}$ & $29.4 \mathrm{~cd}$ & $45.7 \mathrm{~cd}$ \\
D 3 & $23.0 \mathrm{~cd}$ & $33.3 \mathrm{bc}$ & $50.9 \mathrm{bc}$ \\
D 4 & $26.1 \mathrm{ab}$ & $36.4 \mathrm{ab}$ & $54.2 \mathrm{ab}$ \\
D 5 & $23.9 \mathrm{bc}$ & $34.7 \mathrm{~b}$ & $51.5 \mathrm{bc}$ \\
D 6 & $27.5 \mathrm{a}$ & $39.6 \mathrm{a}$ & $58.4 \mathrm{a}$ \\
\hline Mean & 23.3 & 33.5 & 50.4 \\
Threshold & $<0.01$ & $<0.01$ & $<0.01$ \\
LSD & 2.9 & 4.7 & 5.9 \\
\hline
\end{tabular}

depressive effect of the highest densities will increase in the coming years.

Table 12 describes the foliage bulk of palms for each treatment at year 8. A gradient could be observed for the percentage of leaf area overlap between adjacent palms, which was found to increase with density, from $1 \%$ for the lowest density (128 p/ha) up to $50 \%$ for the highest one ( $205 \mathrm{p} / \mathrm{ha})$. It is worth noticing that the ground is not totally covered yet (there is still some empty spaces in the middle of the triangles) for the lowest densities (128 and $143 \mathrm{p} / \mathrm{ha}$ ), while the ground is completely covered at $160 \mathrm{p} / \mathrm{ha}$ density and over. As the frond length continues to increase with age, the bulk will increase too, thus resulting in a stronger competition between palms. Such competition takes place for light interception when a high planting density is used and for the optimization of light interception at low densities once the empty space in the centre is filled. This approach therefore confirms major results from the literature, precisely that the maximum effect of planting density is still yet to come and it is expected to occur at year 10 to 12 .

The palms in treatment D5 were thinned at year 8 in accordance with the experimental protocol (see Tab. 1). To date, the impact of thinning in a monoculture is still under debate: several authors consider this practice as detrimental (Surre, 1955; Coomans, 1974) while others recommend it under specific conditions (Palat et al., 2012). It will be therefore interesting to compare future yield trends in treatments D4 (180 p/ha fixed) and D5 (180 p/ha becoming $154 \mathrm{p} /$ ha at eight years).

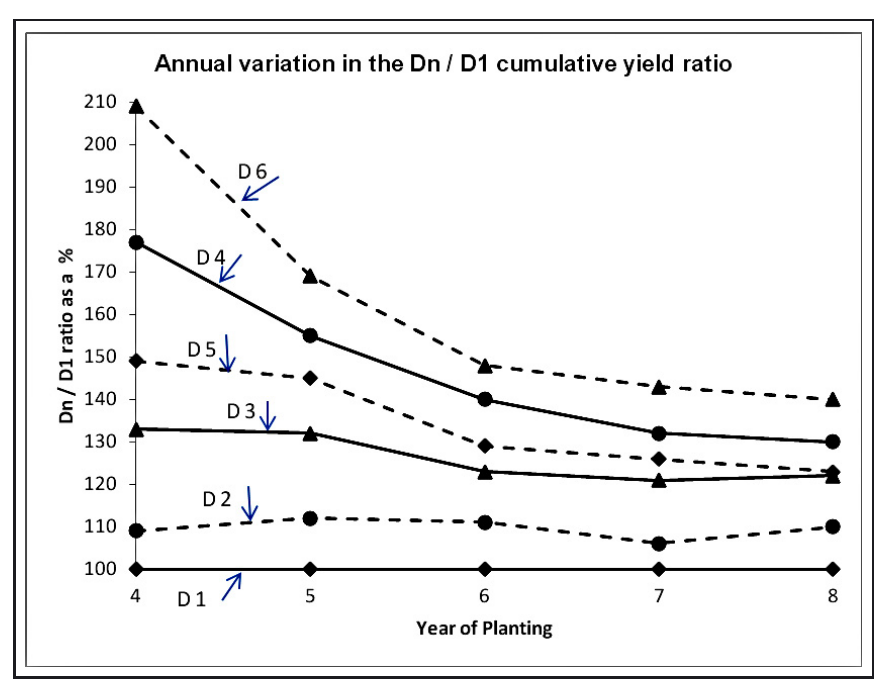

Fig. 2. Changes in the Dn/D1 ratio for cumulative yield.

\section{Conclusion}

The beneficial effect of high planting densities (180 and $205 \mathrm{p} / \mathrm{ha}$ ) at the beginning of the oil palm cultivation cycle recorded in the present experiment comes from the fact that the drop in yields per palm when density is increased does not yet counterbalance the increase in the number of palms per hectare within the range of spacing studied.

Given that the impact of planting density as measured so far is increasing slowly but surely and that the vegetative bulk of the palms will continue to increase, it is expected that such impact will increase over time and will reach its maximum in the near future.

The ultimate goal of the present experiment will be to precisely determine at what age the density effect will reach its maximum, at what age the palms will reach the compensation point and, lastly, what the optimum density will be, when calculated over a full cultivation cycle. Interestingly a continuous canopy now covers the whole experimental plot at year 8, without any hole in the design, thus the present experiment can be safely pursued.

In addition, with the thinning carried out in treatment D5, we shall be able to answer to the following recurrent question in a few years: is the thinning of a plot with a high planting density cost-effective, or is it better to keep the same density throughout the duration of an oil palm cultivation cycle? An 
X. Bonneau et al.: OCL 2014, 21(4) A401

Table 12. Calculation of the oil palm foliage bulk at year 8 in oil palms planted at various densities.

\begin{tabular}{cccccc}
\hline Treatment & $\begin{array}{c}\text { Planting } \\
\text { density }\end{array}$ & $\begin{array}{c}\text { Distance between } \\
\text { palms }(\mathrm{m})\end{array}$ & $\begin{array}{c}\text { Foliage } \\
\text { span }(\mathrm{m})\end{array}$ & $\begin{array}{c}\text { Percentage of } \\
\text { foliage overlap }\end{array}$ & $\begin{array}{c}\text { Percentage of } \\
\text { central void }\end{array}$ \\
\hline D 1 & 128 & 9.5 & 4.86 & 1 & 5 \\
D 2 & 143 & 9 & 4.94 & 9 & 1 \\
D 3 & 160 & 8.5 & 5.05 & 24 & 0 \\
D 4 & 180 & 8 & 5.16 & 38 & 0 \\
D 5 & 180 & 8 & 5.19 & 39 & 0 \\
D 6 & 205 & 7.5 & 5.22 & 50 & 0 \\
\hline
\end{tabular}

NB 1: Foliage span = the distance from the stem to the ground projection of the tip of frond 33. NB 2: Percentage of foliar overlap = by projection of the foliage volume (assimilated to a sphere) on a plane: part of the area of a unit triangle covered by the foliage of 2 or 3 palms (graphic determination).

economic calculation incorporating production factors, such as the cumulative quantity of fertilizers per hectare and the work time depending on the number of palms per hectare (fertilizer application, harvests) will be carried out in order to distinguish between the economic and the agronomic optimal design. As a matter of fact, there are many different aspects to be taken into account when trying to design an optimum planting density for oil palm cultivation (Surre, 1955).

\section{References}

Bonneau X. 1991. Annual report of research in P.T. Multi-AgroCorporation year 1991, May 1992, 50-53. Confidential.

Breure CJ. 2010. Rate of leaf expansion: a criterion for identifying oil palm (Elaieis guineensis Jacq.) types suitable for planting at high densities. Wageningen J. Life Sci. 57: 141-147.

Chen et al., 1989. quoted in Suboh Ismail; Raja Zulfiki; Raja Omar, Kamil Azmi Tohiran (2008). Potentials for integration in oil palm plantations. Planter 84: 303-319.

Coomans P. 1974. Densités de plantation pour le cocotier. Oléagineux 29: 409-414.
De Taffin G, Zakra N, Pomier M. 1992. Densité de plantation et nutrition minérale des cocoteraies. Oléagineux 47: 165-170.

Fernando WMU, Bandaranayake CK. 1996. Effect of planting density on the yield of coconut. Cocos 11: 32-39.

Foale MA. 1968. Early results of coconut density and variety trials. Oléagineux, 23: 721-722.

Henson IE, Mohd Tayeb D. 2003. Physiological analysis of an oil palm density trial on a peat soil. J. Oil Palm Res. 15: 1-27.

Ochs R. 1988. Rapport de mission à P.T. Multi-Agro-Corporation, September 1988, document IRHO 2144/88: 9-12. Confidential.

Palat T, Chayawat N, Corley RHV. 2012. Maximising oil palm yield by high density planting and thinning. Planter 88 : 241-256.

Pau TY, Chan E, 1984. Optimum density for Mawa hybrid. Oléagineux 40: 189-195.

Prévôt P, Duchesne J. 1955. Densités de plantation pour le palmier à huile. Oléagineux 10: 117-122.

Rafii MY, Isa ZA, Kushairi A, Saleh GB, Latif MA, 2013. Variation in yield components and vegetative traits in Malaysian oil palm (Elaeis guineensis Jacq.) dura x pisifera hybrids under various planting densities. Industrial Crops and Products 46: 147-157.

Smith RW. 1972. The optimum spacing for coconuts. Oléagineux 27: 73-86.

Surre C. 1955. Densité économique de plantation pour le palmier à huile. Oléagineux 10: 411-413.

Cite this article as: Xavier Bonneau, Pieter Vandessel, Maxwell Buabeng, Charles Erhahuyi. Early impact of oil palm planting density on vegetative and oil yield variables in West Africa. OCL 2014, 21(4) A401. 